\title{
PRACOVNÍ PRÁVO NA PRAHU ČTVRTÉ PRŮMYSLOVÉ REVOLUCE*
}

\author{
JÁN MATEJKA
}

\begin{abstract}
Labour Law at the Doorstep of the Fourth Industrial Revolution
Czech labor law provides specific general starting points for the introduction of flexible forms of dependent work. In the last decade, however, due to the electronification and globalization of work processes, such significant changes have taken place that current traditional models of these flexible forms prove incompatible with current trends and needs. Globally, these technologies and the regulation itself are changing the paradigm of the workforce, including declining traditional forms of employment and increasing alternative working hours through new technologies and so-called digital work platforms whose disruptive business models (such as Uber, Airbnb, Upwork, or Taskrabbit) create substantial imbalances in social and legal protection and lead to changes in the conditions and nature of work. Therefore, in addition to a general analysis of the conditions under which these platforms operate, this article also covers considerations for future regulation, including reflection at the level of EU law. The evaluation of related strategy papers, whether national or European, is not left out of these considerations, including partial considerations concerning some related aspects of the relationship between work and current technologies.
\end{abstract}

Keywords: flexible forms of work; shared economy; artificial intelligence; technological unemployment; universal income; Insdustry 4.0; collaborative economy (peer-to-peer economy); crowdworking

Klíčová slova: flexibilní formy výkonu práce; sdílená ekonomika; umělá inteligence; technologická nezaměstnanost; univerzální př́ijem; Průmysl 4.0; sdílená ekonomika; crowdworking

DOI: $10.14712 / 23366478.2021 .9$

* Př́spěvek vznikl za podpory projektu Technologické agentury ČR č. TL03000152 s názvem Umělá inteligence, média a právo. 
„Máme tendenci přeceňovat vliv technologie v krátkodobém horizontu a podceňovat efekt v dlouhodobém horizontu."

Roy Charles Amara ${ }^{1}$ (1925-2007)

\section{1. ÚVODEM K PROPOJENÍ TECHNOLOGIE A LIDSKÉ PRÁCE}

Počátkem druhé poloviny února tohoto roku přistál na Marsu americký průzkumný robot Perseverance (Vytrvalost), a to krátce poté, co na vteřinu přesně a bez sebemenší odchylky z plánované trajektorie zvládl jeho nosný modul provést složitý přistávací manévr pojmenovaný mediální zkratkou „sedm minut hrùzy“. Součástí tohoto průzkumného robota byl rovněž vrtulník Ingenuity (Vynalézavost) a řada dalších přistrojů určených pro výzkum povrchových i podpovrchových struktur planety a jejich chemickou analýzu. ${ }^{2}$ Všechny tyto vysoce rizikové a sofistikované úkony, včetně jejich dalšího využívání, byly či budou realizovány zcela autonomně, a s ohledem na časový posun (cca 12 minut), bez jakékoliv přímé operativní kontroly či dohledu člověka v reálném čase, a to navzdory skutečnosti, že ještě před pár lety by podobný úkon vyžadoval přímé řízení vysoce trénovaného a edukovaného pilota.

Žijeme v době, kdy i ty nejsložitější úkony, jež byly dosud vyhrazeny pouze vyvoleným, provádějí plně autonomní systémy, a to zcela bez účasti člověka. Tyto změny tak navzdory relativně krátké době své existence přináší široké ekonomické, společenské změny, jež mají ze své podstaty přesahy i do oblasti právní politiky a regulace. Rychlost rozvoje těchto autonomních technologií, včetně zavedení robotizace a nasazení prvků umělé inteligence (AI) a dalších technologií do výroby a služeb, včetně forem jejich řízení, pak přináší řadu praktických právních problémů, jež ve svém důsledku vedou $\mathrm{k}$ proměnám nejenom zavedených pracovních postupů a podmínek realizace těchto služeb, ale také kladou zcela nové požadavky na znalosti a dovednosti všech klíčových aktérů relevantních právních vztahů. Analyzovat a popsat průnik všech těchto dynamických veličin, tj. zejména nových technologií ve vazbě na budoucnost právní úpravy, včetně samotných odpovědnostních přesahů, je úkol v mnohém nesnadný, nebot' do jisté míry implikuje nezřídka téměř protikladný vývoj názorů na postavení a odpovědnost člověka ve společnosti, stejně tak jako na vztah jeho svobody, jeho práv a povinností.

Lidská práce je navíc nedílně propojena s technologiemi, nebot' zatím stále ještě představuje conditio sine qua non jakéhokoliv technologického rozvoje, kde platí, že bez (lidské) práce žádná technologie nevznikne. Technologie není o nástrojích, zabývá se především tím, jak člověk pracuje, jak správně potvrzuje americký filosof P. F. Drücker (1909-2005), který v roce 1959 zkoumal technologické vynálezy a jejich použití během průmyslové revoluce, kde došel k závěru, že: „Technologie není o věcech, o nástrojích,

1 Roy Charles Amara byl americký výzkumník, vědec, futurista a prezident Institutu pro budoucnost, nejlépe známý pro vytvárení tzv. Amarina zákona o vlivu technologie. Více viz Roy Amara. In: Wikipedia [online]. 7. 12. 2020 [cit. 2021-02-23]. Dostupné na: https://en.wikipedia.org/wiki/Roy_Amara.

2 K tomu více viz NASA Science: Mars 2020 Mission Persevance Rover [online]. [cit. 2021-02-23]. Dostupné na: https://mars.nasa.gov/mars2020. 
postupech a výrobcích. Jde o práci, konkrétně lidská činnost, jejímž prostřednictvím člověk odsouvá omezení železného biologického zákona, který odsuzuje všechna ostatní zvírata k tomu, aby věnovala veškerý svi̊j čas a energii tomu, aby se udržela naživu dalši den, ne-li další hodinu... Sférou a předmětem studia technologie je lidská práce... Jejím cílem bylo zvýšení lidské kapacity."3

Vývoj společnosti (i technologie), jež je nedílně svázán s problematikou výkonu práce, prochází rozsáhlou transformací. Kromě digitalizace, globalizace podniků a flexibilizace jejich organizačních forem se mění i hlavní paradigmata a podmínky jejich fungování, což má významné důsledky jak pro zaměstnavatele samotné, tak i pro formy výkonu práce realizované u těchto zaměstnavatelů. $\mathrm{V}$ obecné rovině je třeba zdůraznit, že dochází ke změně hodnot ve společnosti jako celku, at' již jde o hledání určité harmonie propojení rodinného a pracovního života, problematiky zaměstnanosti a trhu práce, případně ostatních prvků rovnováhy života. Právě určitá rovnováha mezi pracovním a soukromým životem hraje mezi těmito atributy klíčovou roli, nebot' elektronizace, resp. digitalizace (on-line) života, demografický vývoj, environmentální problémy, jako je energetická politika nebo elektrifikace pohonů $\mathrm{v}$ automobilovém průmyslu, problematika migrace a rostoucí touha lidí po účasti, zejména po zapojení zaměstnanců do rozhodování managementu, jsou klíčové faktory uvedené transformace.

Veškerý tento sociální vývoj tak klade výrazně vy̌šsí nároky na činnost odborových organizací, zástupců zaměstnanců a zaměstnavatelů, jakož i celé řady dalších entit způsobilých více či méně spolurozhodovat se zaměstnavateli, př́ípadně ovlivňovat jejich další prrístup k formování pracovního života. Určitými nosnými mantinely tohoto vývoje, jež bude určovat kvalitu i směr tohoto souvisejícího diskurzu, budou zpravidla dva co do př́stupu odlišné pohledy. Na jedné straně zde bude určitým mantinelem patrně názor anglického ekonoma Johna Maynarda Keynese, jenž v obecné rovině vždy považoval „technologickou nezaměstnanost“ za určité přechodné období, jež bude brzo překonáno tvorbou dostatečného počtu nových pracovních míst. ${ }^{4} \mathrm{Na}$ straně druhé zde budou existovat opačné názory, jež budou vycházet ze společenské poptávky po určitém univerzálním (základním) př́ijmu, kterým bude společnost (stát) kompenzovat dlouhodobou „technologickou nezaměstnanost“ vůči každému, kdo se stal v důsledku tohoto vývoje nezaměstnaným. ${ }^{5}$

3 Viz DRÜCKER, P. T. Technology, Management and Society. New York: Harper \& Row Publishers, 1970, s. 2.

4 K této tezi se ostatně opakovaně hlásil i americký prezident John Fitzgerald Kennedy (1917-1963), jenž věřil, že „pokud mají lidé talent vymýšlet nové stroje, které je o práci připraví, musí mít rovněž talent tyto lidi zpět do práce navrátit“. Viz RATCLIFFE, S. (ed.). Oxford Essential Quotations [online]. 6th ed. Oxford: Oxford University Press, 2018 [cit. 2020-06-09]. Dostupné na: http://www.oxfordreference.com /view/10.1093/acref/9780191866692.001.0001/q-oro-ed6-00018679?rskey=xeSbvM\&result=91.

5 K tomu více viz např. LAU, J. Future of Work in an Age of Automation, Artificial Intelligence and Technology. International In-House Counsel Journal. 2020, Vol. 13, No. 52; případně též FORD, M. Introduction. In: Rise of the Robots: Technology and the Threat of a Jobless Future. New York: Basic Books, 2015, s. XV; SUSSKIND, R. - SUSSKIND, D. The Future of the Professions: How Technology Will Transform the Work of Human Experts. Oxford: Oxford University Press, 2015, s. 283, 289, 291-295. 


\section{FLEXIBILNÍ PRACOVNÍ PLATFORMY JAKO DŮSLEDEK DIGITALIZACE A GLOBALIZACE}

Důsledkem elektronizace a stále více se globalizujících procesů společnosti, jakož i logické potřeby sladit soukromé a pracovní sféry života člověka, došlo během posledních dvou dekád $\mathrm{k}$ výraznému rozšrir̃ení portfolia dosavadních forem zaměstnávání. Mezi tyto relativně nové (a do jisté míry flexibilnî) formy patř́ jak relativně tradiční instituty typu dohod o pracích konaných mimo pracovní poměr, tak i instituty relativně novější, jako je např. konto pracovní doby ( 886 a 87 zákoníku práce), agenturní zaměstnávání, dočasné přidělení zaměstnance, institut částečné nezaměstnanosti, úprava (pružné) pracovní doby a možností jejího rozvržení (\$ 81 zákoníku práce), případně také výkon práce z domova či sdílení pracovního místa. Tyto flexibilní formy výkonu práce reagují nejenom na současné technologické možnosti, ale reflektují také volný a relativně pružný způsob výkonu práce zohledňující individuální potřeby zaměstnance i zaměstnavatele. Svou podstatou tak představují pozvolné a svou podstatou spíše dílčí změny, jež zásadně podstatu výkonu práce neovlivňují, nebot' jimi zákonodárce pouze stanovil určité mantinely dispozitivity, a to se zřetelem k naplnění klíčové maximy pracovního práva, jímž je především jeho ochranná funkce.

Kromě těchto zákonem výslovně předpokládaných flexibilních forem regulovaných výlučně na půdorysu předpisů upravujících závislou práci, a tedy i ochrany ve smyslu práva pracovního i práva sociálního zabezpečení, však dochází k celkové flexibilizaci vztahů přesahující mantinely pracovněprávní regulace (i ochrany), a to nejenom na národní úrovní, ale př́edevším na úrovni nadnárodní. Jeden z typických prŕíkladů tohoto typu pak představují tzv. služby sdílené ekonomiky, ${ }^{6}$ tedy svého druhu určité digitální pracovní platformy, jež na základě různých obchodních modelů, jejichž rozvoj (penetrace) jde ruku v ruce s rozvojem znalostní, resp. digitální ekonomiky, a tedy pro své efektivní fungování vyžaduje vybudovanou infrastrukturu pro vysokorychlostní internet, společenskou dostupnost specifických elektronických prostředků v dispozici všech jejích aktérů (včetně softwaru), bez kterých tyto platformy nemohou fungovat.

Souvisejícím předpokladem efektivního fungování těchto nových platforem však není dostupnost pouze shora uvedené existence digitálních platforem (digitalizace), ale současně také jejich existence v globálním prostředí. Právě současné propojení globalizace a digitalizace společností představují vzájemně se urychlující a podporující procesy. Podstatná část nadnárodních korporací v nějaké formě využívá tohoto efektu, na což reaguje stále více se rozšiřujícími digitálními a celosvětově distribuovanými funkcemi, včetně nákupu služeb a věcí, výroby, výzkumu či vývoje apod. Narůstající dynamika těchto globálních procesů bývá zpravidla nedílně spojena s určitou „Big data analýzou"7 vyhodnocující celkovou efektivitu těchto procesů, jež vnesla do těchto

6 Mnohdy též nazývané kolaborativní ekonomika (collaborative economy, př́padně peer-to-peer economy, access economy, pooling economy).

7 Big Data zpravidla přestavují určitá jinak neupravená data, jejichž uchování a zpracování přesahuje možnosti běžných prostředků technologií. Big Data vznikají z různých forem elektronické výměny dat, z elektronických činností či záznamů (např. z výrobních procesủ nebo z aktivit v sociálních médiích). Definice Big Data se zdroj od zdroje liš́. Pojem samotný poprvé definoval Roger Magoulas v roce 2005, a to jako obecný zastřešující pojem pro širokou škálu velkých datových sad, které není možné třídit a zpracovat za použití tradičních 
procesů určitou transparentnost a urychlila jejich rozhodování, často s centrálními cíli a vysoce decentralizovanou realizací. Jak již bylo řečeno výše, právě globalizace samotná pak poskytuje těmto digitálním nástrojům obrovskou flexibilitu a, co se např. výroby či dodávek týče, tak i efektivitu. Vliv těchto nadnárodních entit tak neustále roste po celém světě. ${ }^{8}$

Existence těchto nových flexibilních platforem byla předmětem celé řady zdařilých publikací, ${ }^{9}$ a to navíc v šriri přesahující možnosti tohoto článku. Při určitém zobecnění této problematiky však lze tyto platformy popsat jako zpravidla trojstranné závazkové vztahy mezi poskytovatelem a objednatelem služby, existující zpravidla bez jakékoliv sociální ochrany, a realizované v prostředí digitální platformy s globálním přesahem.

Tyto platformy se v obecné rovině považují za určitého zprostředkovatele práce či služeb, přičemž spektrum jejich činnosti je nepřeberně široké, od dopravy (Lyft, Uber), přes pomoc v domácnosti (TaskRabbit, Instacart), konzultanty (NBA Consultants), lékaře (Medicast) a právníky (Advocado) až po crowdworking (AMT, Upwork). Jinými slovy platformy tohoto typu dnes existují téměř v každém odvětví průmyslu či ekonomiky, přičemž se postupně stávají co do druhu činnosti významným zaměstnavatelem (largo sensu). ${ }^{10}$ Jak již bylo zmíněno, platformy chtějí být považovány za pouhé zprostředkovatele, jejich zaměstnanci pak stojí v relativně nezávislém postavení, tj. bez jakékoliv sociální či pracovněprávní ochrany. Zaměstnanci tak nesou veškerá rizika výkonu práce, včetně odpovědnosti za svěřené či vlastněné prostředky související s výkonem práce apod. Výkon práce pro tyto platformy je tak postaven na relativní nezávislosti a je v zásadě srovnatelný s výkonem tzv. samostatné výdělečné činnosti.

Jakkoliv existují mezi shora uvedenými platformami významné rozdíly, a to ve smyslu rozsahu dohledu, resp. dozoru, případně výběru okruhu potenciálních dodavatelů či pracovníků, v zahraničí se pro tyto vztahy zpravidla používá zastřešující pojem crowdworking,$^{11}$ představující formu výkonu práce (služby) zadávané prostřednictvím digitální platformy do relativně anonymního davu (z předem známého okruhu adresátů). ${ }^{12}$ Tyto flexibilní pracovní platformy mohou mít různý právní i faktický režim. Crowdworking lze rovněž provádět interně (např. v rámci jedné globálně existující

nástrojů, a to právě kvůli jejich komplexitě a velikosti. K tomu více viz např. HALEVI, G. - MOED, H. F. The Evolution of Big Data as a Research and Scientific Topic: Overview of the Literature. Research Trends [online]. 2012 [cit. 2021-02-23]. Dostupné na: http://www.researchtrends.com/issue-30-september-2012 /the-evolution-of-big-data-as-a-research-and-scientific-topic-overview-of-the-literature/.

8 Podle WTO např. téměř čtvrtina zaměstnanců kromě zemědělství pracuje pro 104000 nadnárodních společností a jejich přibližně 900000 dceřiných společností. K tomu více KLEBE, T. - WEISS, M. Workers' Participation 4.0 - Digital and Global. Comparative Labor Law \& Policy Journal. 2019, Vol. 40, No. 2, s. 263-284.

9 Z nedávných publikací např. PICHRT, J. - BOHÁČ, R. - MORÁVEK, J. Sdílená ekonomika tři roky poté - závěry a perspektivy. Praha: Wolters Kluwer, 2019, s. 138-144.

10 Tyto platformy již v současnosti zaměstnávají miliony lidí, např. Amazon Mechanical Turk (AMT) tvrdí, že má 500000 uživatelů a Upwork více než 8 milionů s 250 stálými zaměstnanci. Podle manažerských poradců PWC bude do roku 2025 pravděpodobně obrat v pěti klíčových odvětvích kolem 335 miliard dolarů. To je považováno za konzervativní odhad. K tomu více viz KLEBE - WEISS, c. d., s. 263-284.

11 K pojmu crowdworking více viz JÄGER, G. - ZILIAN, L. S. - HOFER, C. et al. Crowdworking: working with or against the crowd? J Econ Interact Coord [online]. 2019, No. 14, s. 761-788 [cit. 2021-02-23]. Dostupné na: https://doi.org/10.1007/s11403-019-00266-1.

12 Pojem crowdsourcing poprvé použil Jeff Howe v červnu 2006 v článku pro časopis Wired. Př́íklady crowdsourcingových projektů se uskutečňovaly ale výrazně dříve. Např. roku 1714 britská vláda nabídla 
korporace, jako je tomu např. u softwarové platformy Open Generation od společnosti IBM nebo Daimler's Business Innovation), př́ípadně zcela externě vůči všem, tj. tak, že je konkrétní výzva, aby někdo něco vykonal (tj. převzal určitý úkol), př́ípadně se jinak zavázal (např. př̀vzal provizi), zaslána vůči předem vymezené skupině potenciálních pracovníků (crowdworkerů). Crowdwork se tak může vyskytovat v zásadě ve všech částech dodavatelského řetězce a může zahrnovat jednoduché a dílčí úkoly, stejně tak jako velmi složité vědecké otázky v medicíně, matematice nebo designu. Mezi pravidelné provozovatele i uživatele těchto platforem tak patří mimo jiné i velcí a renomovaní zaměstnavatelé, jako je např. Google, NSA, Intel, AOL, Telekom, BMW, Honda, Panasonic, Microsoft, Unilever, Audi a Airbus. ${ }^{13}$

Pracovní podmínky crowdworkrů se v různých př́ípadech liší, zpravidla jsou ale často velmi nejisté. Svou podstatou jde o otevřené platformy, a to nejenom pro profesionály, ale také studenty či začátečníky ve svých oborech, což je reflektováno i v průměrných výdělcích. ${ }^{14}$

Celkově vzato stojí crowdworkeři mimo režim ochranných institutů pracovního práva a práva sociálního zabezpečení, nezřídka pak i v důsledků volby „vhodného“ rozhodného národního práva také mimo ochranné instituty ostatních právních odvětví. Crowdworkeři tak nemají zpravidla žádnou ochranu před propuštěním, nemají nárok na dovolenou ani na minimální mzdu. Ze stejných důvodů na ně nedopadá ani ochranný režim (sektorových) kolektivních smluv, včetně ochrany poskytované odborovými organizacemi, podnikovými radami a jinými orgány spolurozhodujícími se zaměstnavatelem. Pravidla upravující právní vztah mezi digitální platformou, zákazníkem i poskytovatelem jsou obvykle upravena pouze $\mathrm{v}$ obchodních podmínkách př́slušných nadnárodních společností, jež bývají navíc nezřídka jednostranně měněny apod.

Tyto podmínky zpravidla pak nijak nereflektují evropské či národní standardy ochrany soukromí výkonu práce či určitou proporcionalitu při zpracovávání osobních údajů. ${ }^{15}$ Právě vyvážená ochrana provozních a souvisejících dat o výkonu práce se jeví jako významný atribut ochrany práv crowdworkerů, protože je to právě digitalizace, která umožňuje zachytit a modelovat všechny pracovní fáze crowdworkingu, včetně chování zaměstnancủ a zákazníků. Možnost transparentního dohledu nad technologickým monitoringem lze do jisté míry považovat za souladný se zájmy zaměstnanců a lze jej zahrnout také do rozsahu účelu určitého standardu ochrany, např. za účelem ověření pracovního výkonu, ochrany zdraví apod. Právě z důvodu existence širokého spektra těchto

veřejnou odměnu za vyřešení úlohy související se zeměpisnou délkou. K tomu více viz např. Crowdsourcing. In: Wikipedia [online]. [cit. 2021-02-23]. Dostupné na: https://en.wikipedia.org/wiki/Crowdsourcing.

13 Celosvětově existuje přibližně 2300 crowdworkových platforem, z nichž alespoň třicet dva má fyzické umístění v Německu (do února 2017). Viz KLEBE - WEISS, c.d., s. 268.

$14 \mathrm{~V}$ př́ípadě Německa uvádí zpráva německého Ministerstva práva a sociálních věci (BMAS), že průměrný výdělek těchto platforem činí 200 EUR měsíčně. Výzkumný projekt nadace Hans-Böckler-Foundation uvádí následující údaje: pracovníci získávají průměrný měsíční př́íjem 1503 EUR v hlavní činnosti (přibližně $20 \%$ crowdworkeri̊), zatímco v dalších činnostech je to 326 EUR před zdaněním. K tomu více viz LEIMEISTER, J. et al. Crowdwork in Deutschland: Eine empirische Studie zum Arbeitsumfeld aufexternen Crowdsourcing-Plattformen [Crowdwork in Germany: an empirical study on the Working environment on external crowdsourcing platforms]. Study der Hans-Böckler-Stiftung, No. 323. Düsseldorf: Hans-Böckler-Stiftung, 2016.

15 Viz KLEBE - WEISS, c.d., s. 269. 
dat, a jejich vysoké vypovídající hodnoty, je zde dán do budoucnosti široký prostor pro efektivní regulaci, včetně možnosti zástupců crowdworkerů, odborových organizací, včetně sektorových kolektivních smluv.

\section{VYUŽÍVÁNÍ SYSTÉMŮ UMĚLÉ INTELIGENCE A AUTOMATIZACE}

Konkrétní dopady zavádění prvků umělé inteligence v pracovněprávních vztazích je dnes možno spíše jen odhadovat než přesně předvídat. Konkrétní význam lze spíše spatřovat v promítnutí existujících evropských či národních politik do právní úpravy, př́ípadně v postupném nasazování vybraných prvků umělé inteligence $(\mathrm{AI}) \mathrm{v}$ jejich slabších verzích, jež jsou bližší současnému stavu technologického rozvoje v oblasti digitalizace a do jisté míry i robotiky.

Tyto prvky již dnes jistě plní některé své funkce, a to zpravidla bud' v oblasti analýzy, případně automatizace, komplexnější dopady lze jistě očekávat, avšak po odstranění celé řady překážek, jež stojí v cestě jejich masivnějšímu nástupu. Jakkoliv jde do jisté míry o dostupné technologie, tak k plnému a zejména funkčnímu nasazení naprosté většiny z nich, jako jsou např. autonomní vozidla či autonomní bezpilotní letadla neboli drony, brání existující právní překážky, v důsledku nichž je nelze komplexně využívat, protože to právní úprava přímo vylučuje. ${ }^{16}$ Využití umělé inteligence je však všestranné, a tedy potřeba vhodné regulace se netýká jedné specifické právní oblasti, ale představuje komplexní problematiku pro právní politiku, vědu i etiku.

Z pohledu práva a právní vědy je umělá inteligence poměrně nesnadno uchopitelná. Není to ale jenom kvůli její univerzální využitelnosti a širokému uplatnění. Tato technologie se vyznačuje několika charakteristikami, které jsou pro právo velkou výzvou. Inteligentní systémy totiž dokáží fungovat relativně nezávisle na člověku (tj. bez jeho dohledu), mají při svém rozhodování určitou míru autonomie. Některé se dokáží vyvíjet $\mathrm{v}$ čase v závislosti na interakci s okolím a u řady aplikací ${ }^{17}$ není možné s jistotou určit, proč systém učinil určité konkrétní rozhodnutí. V této souvislosti se mluví o tzv. black-boxu, který vyvolává pochybnosti o tom, zda je možné spolehnout se na tyto systémy při řešení důležitých problémů, což má své přesahy do oblasti právní odpovědnosti, zejména pak prokazatelnosti, kauzality, resp. přičitatelnosti, konkrétního jednání. ${ }^{18}$

16 K tomu více viz KRAUSOVÁ, A. - MATEJKA, J. - IVANČO, A. - ŽOLNERČÍKOVÁ, V. - ŠČÉRBA, T. Výzkum potenciálu rozvoje umělé inteligence v České republice: analýza právně-etických aspektů rozvoje umělé inteligence a jejích aplikací v ČR [online]. Technologická agentura České republiky, České vysoké učení technické v Praze, 2018 [cit. 2021-02-23]. Dostupné na: https://www.vlada.cz/assets/evropske-zalezitosti/aktualne/AI-pravne-eticka-zprava-2018_final.pdf.

17 Jde zejména o umělé neuronové sítě a v jejich rámci o tzv. hluboké učení (deep learning).

18 Právě relativní nepředvídatelnost, a tedy snížená kontrola člověka nad těmito systémy, je dalším z důvodů, proč právo začalo umělou inteligenci zkoumat. K tomu více viz BENÍTEZ, J. M. - CASTRO, J. L. REQUENA, I. Are Artificial Neural Networks Black Boxes? IEEE Transactions on Neural Networks. 1997, Vol. 8, No. 5, s. 1156-1164 [cit. 2019-09-29]. Dostupné na: https://www.researchgate.net/profile /Juan_Castro15/publication/5595919_Are_Artifi_cial_Neural_Networks_Black_Boxes/links/09e4150 d40ff685694000000/Are-Artifi-cial-Neural-Networks-Black-Boxes.pdf. 
Tak, jako neexistuje jednotná definice z technického pohledu, tak neexistuje žádná právní definice umělé inteligence, byt' např. na úrovni dokumentů Evropské unie existují právně nezávazné definice. Evropská komise přišla v dubnu 2018 s následující specifikací: „,Umělá inteligence (AI, případně dle kontextu autonomní systémy) odkazuje na systémy, které vykazují inteligentní chování tím, že analyzuji své prostředí a jednají - s jistou mírou autonomie - tak, aby dosáhly určitých specifických cílù. Systémy založené na AI mohou mít čistě softwarovou povahu a jednat ve virtuálním světě (např. hlasoví asistenti, software na analýzu obrazu, vyhledávače, systémy na rozpoznávání hlasu a obličeje) nebo mohou být vestavěny do hardwarových zařizení (např. pokročilí roboti, autonomní vozidla, drony, nebo aplikace internetu věcí). "19 Tento text poměrně dobře ilustruje, že na AI je třeba se dívat z pohledu různých právních odvětví. Konkrétní aplikace umělé inteligence může být považována např. za počítačový program, věc, výrobek, službu nebo za počítačový virus ${ }^{20}$ Kromě toho zasahuje do velkého množství různorodých právem regulovaných vztahů.

Hlavním dokumentem, který v podstatě odstartoval vášnivé debaty o umělé inteligenci a autonomních robotech, bylo usnesení Evropského parlamentu ze dne 16. 2. 2017 s názvem „Občanskoprávní pravidla pro robotiku“. ${ }^{21}$ Evropský parlament, který při formulaci usnesení vycházel z vlastní studie „Ethical Aspects of Cyber-Physical Systems“ ${ }^{22}$ v tomto dokumentu nastínil hlavní právní a etické problémy týkající se robotů a umělé inteligence, přičemž na prvním místě doporučil vytvořit „obecně přijatelnou definici robota a umělé inteligence, která bude pružná a nebude bránit inovacím “. Hlavním tématem celého usnesení je snaha poukázat na problematické momenty v přístupu k odpovědnosti, zejména na ztrátu kontroly člověka nad technologií, která se chová do jisté míry autonomně a nemůže tak již být považována za pasivní nástroj, ale je vzhledem ke své schopnosti interakce s okolím spíše připodobňována k aktivnímu aktérovi. Usnesení zmiňuje problematičnost vysledování př́ćciny chování inteligentního systému k určitému subjektu a klade si otázku, ,zda by měla být vytvořena nová kategorie s vlastními specifickými rysy a di̊sledky “. Zároveň poukazuje na to, že se platná právní úprava nedovede vyrovnat s případy škody způsobené autonomními roboty, kteří mají schopnost samostatně se učit, a jsou tudíž nepředvídatelní. Evropský parlament pak vyzdvihuje roli etických zásad a potřebu jasných pravidel. Pro řešení odpovědnostních otázek dává ke zvážení dva přístupy - přístup absolutní odpovědnosti (tzv. objektivní odpovědnost, při níž se nevyžaduje prokazování zavinění, ale pouze důkaz o vzniku škody a příčinné souvislosti - v českém právu jde např̀. o odpovědnost

19 Communication from the Commission to the European Parliament, the European Council, the Council, the European Economic and Social Committee and the Committee of the Regions. Artificial Intelligence for Europe. In: European Commission [online]. 25. 4. 2018 [cit. 2019-09-29]. Dostupné na: https://ec.europa .eu/digital-single-market/en/news/communication-artificial-intelligence-europe. [Vlastní překlad autora z angličtiny.]

20 K tomu více viz KRAUSOVÁ - MATEJKA - IVANČO - ŽOLNERČÍKOVÁ - ŠČÉRBA, $c . d$.

21 Usnesení Evropského parlamentu ze dne 16. 2. 2017 obsahující doporučení Komisi o občanskoprávních pravidlech pro robotiku (2015/2103(INL)). In: Evropský parlament [online]. 2017 [cit. 2019-09-29]. Dostupné na: http://www.europarl.europa.eu/doceo/document/TA-8-2017-0051_CS.html.

22 STOA. Ethical Aspects of Cyber-Physical Systems: Scientific Foresight study [online]. European Parliament, 2016 [cit. 2019-09-29]. Dostupné na: http://www.europarl.europa.eu/RegData/etudes /STUD/2016/563501/EPRS_STU\%282016\%29563501_EN.pdf. 
za škodu z provozu dopravních prostředků) a přístup založený na řízení rizik (podle něj by měla být odpovědnou osoba, ,která je za určitých okolností schopna minimalizovat rizika a ř ě̌it negativní dopady "). ${ }^{23}$ Evropský parlament nicméně ještě navrhl, aby bylo do budoucna zváženo, zda by neměl být pro ty nejsložitější autonomní roboty navržen status tzv. elektronické osoby. ${ }^{24}$

Na konci srpna 2017 se k problematice regulace umělé inteligence vyjádřil i Evropský hospodářský a sociální výbor, který ve svém stanovisku „Dopady umělé inteligence na jednotný trh (digitálnî), výrobu, spotřebu, zaměstnanost a společnost“"25 definuje 11 oblastí, kterých se AI významně dotýká. Jsou jimi „etika, bezpečnost, soukromí, transparentnost a vysvětlitelnost, práce, vzdělávání a schopnosti, (ne)rovnost a začleňování, právní předpisy a regulace, správa a demokracie, válka, superinteligence ". ${ }^{26}$ Hlavním doporučením je pak přístup human in command, v rámci kterého si člověk vždy ponechává nad AI kontrolu. S ohledem na toto doporučení se pak EHSV staví negativně i vůči zavedení konceptu elektronické osoby a považuje jej za „nepřijatelný morální hazard “, který by ohrozil preventivní působení norem občanskoprávní odpovědnosti. ${ }^{27}$

Rovněž Česká republika na vývoj na úrovni Evropské unie aktivně reaguje. V roce 2018 si nechal Úřad vlády zpracovat rozsáhlou studii, která se věnuje třem oblastem pozici České republiky v oblasti technologického rozvoje umělé inteligence, ${ }^{28}$ očekávaným socioekonomickým dopadům rozvoje AI v České republice ${ }^{29}$ a právně-etickým aspektům rozvoje umělé inteligence a jejich aplikací v České republice..$^{30}$ Nejdůležitější poznatky všech tří studií jsou pak uvedeny v souhrnné zprávě. ${ }^{31}$ Co se týče právních otázek, tak studie hodnotí připravenost českého práva „na nové aplikace umělé inteligence zejména s ohledem na umožnění a ochranu inovací při současném zajištění efektivity práva ve společnosti“.32

23 Usnesení Evropského parlamentu ze dne 16. 2. 2017 obsahující doporučení Komisi o občanskoprávních pravidlech pro robotiku (2015/2103(INL)).

${ }^{24} \mathrm{~K}$ této problematice blíže viz KRAUSOVÁ, A. Status elektronické osoby v evropském právu v kontextu českého práva. Právní rozhledy. 2017, č. 20, s. 700 a násl.

25 Stanovisko Evropského hospodářského a sociálního výboru k tématu Umělá inteligence - dopady umělé inteligence na jednotný trh (digitální), výrobu, spotřebu, zaměstnanost a společnost (stanovisko z vlastní iniciativy) (2017/C 288/01) [online]. 2017 [cit. 2019-09-29]. Dostupné na: https://eur-lex.europa.eu /legal-content/CS/TXT/HTML/?uri=CELEX:52016IE5369.

26 Tamtéž, bod 1.5 .

27 Tamtéź, bod 3.33.

28 KRÁL, L. a kol. Výzkum potenciálu rozvoje umělé inteligence v České republice: výzkumné, technologické a podnikové zázemí v ČR: analýza pozice České republiky v oblasti technologického rozvoje umělé inteligence [online]. Úřad vlády České republiky, 10. 12. 2018 [cit. 2019-09-29]. Dostupné na: https:// www.vlada.cz/assets/evropske-zalezitosti/aktualne/AI-technologie-2018.pdf.

29 FAŤUN, M. a kol.Výzkum potenciálu rozvoje umělé inteligence v České republice: analýza očekávaných socioekonomických dopadů rozvoje v ČR [online]. Úřad vlády České republiky, 10. 12. 2018 [cit. 2019-09-29]. Dostupné na: https://www.vlada.cz/assets/evropske-zalezitosti/aktualne/AI_socioekonomicke_dopady _2018.pdf.

30 KRAUSOVÁ - MATEJKA - IVANČO - ŽOLNERČÍKOVÁ - ŠČÉRBA, $c . d$.

31 FAŤUN, M. a kol. Výzkum potenciálu rozvoje umělé inteligence v České republice: souhrnná zpráva [online]. Úřad vlády České republiky, 10. 12. 2018 [cit. 2019-09-29]. Dostupné na: https://www.vlada.cz /assets/evropske-zalezitosti/aktualne/AI-souhrnna-zprava-2018.pdf.

32 Tamtéž, s. 9. 
Na zmíněné odborné studie navázala Česká republika vytvořením Národní strategie umělé inteligence v České republice, ${ }^{33}$ která byla schválena usnesením vlády ČR ze dne 6. května 2019 č. $314 .{ }^{34}$ Studie je však pojata značně obecně, nepokrývá konkrétní dopady do oblasti pracovněprávních vztahů, včetně problematiky trhu práce a zaměstnanosti. Zmiňuje pouze očekávaný disruptivní dopad AI technologií na trh práce, tj. dopad nejen na práci s nízkou a střední kvalifikací, ale prakticky na všechny typy zaměstnání, včetně profesí vyžadujících vysokou kvalifikaci s vysokým platovým ohodnocením. ${ }^{35}$ Vzhledem ke struktuře pracovní síly v ČR a ke způsobu zapojení ČR do globálních hodnotových řetězců lze očekávat, že ČR bude patřit mezi země, jejichž profesní struktura bude vystavena největší změně. ${ }^{36}$ Tomu bude potřeba přizpůsobit nejen systém sociálního zabezpečení a rekvalifikace, ale především celý proces vzdělávání. ${ }^{37}$

Jakkoliv to vládní strategie přímo nereflektují, lze soudit, že dopady prvků umělé inteligence na trh a do oblasti pracovněprávní budou nemalé. Současný vývoj Průmyslu 4.0 totiž není srovnatelný s jakýmkoliv předchozím vývojem. Právě existence dostupného internetu, pokročilá globalizace velkých zaměstnavatelů, a tedy i digitálních platforem, mimořádný nárůst schopností počítačů tento vývoj jasně ilustruje. Tato čtvrtá průmyslová revoluce, mnohdy nazývaný Průmysl 4.0, probíhá na základě kyberneticko-fyzikálních systémů. Informační a výrobní technologie jsou propojeny prostřednictvím datové infrastruktury, jakou jsou sdílené platformy a internet. Pracovníci budou do těchto sofistikovaných systémů zapojeni prostřednictvím rozhraní, jako jsou chytré telefony, tablety, př́padně specifické komponenty z řad tzv. nositelné elektroniky. ${ }^{38}$ Tato rozhraní, používající prvky umělé inteligence zpracovávají již dnes v reálném čase enormní množství souvisejících dat (opět formou Big Data analýzy), což povede k operativnímu přizpůsobení výroby aktuálnímu stavu objednávky a přání zákazníků, spolu s předpovědí o dalším chování zákazníků, včasné detekci závad, a tím i preventivní údržbě a opravě. V této souvislosti budou rovněž zpracovávány údaje o zaměstnancích, nebot' jen oni mohou být přriřazeni k určitým výrobním procesům a strojům.

Umělá inteligence se tak již dnes stává určitým nezpochybnitelným fenoménem, jehož prostřednictvím bude docházet ke spolupráci mezi autonomními systémy a lidmi, jakož i k celkové organizaci práce. Zatímco některé systémy budou zpravidla pracovat samostatně (autonomně), jiné systémy budou s pracovníky přímo interagovat, napřr.

33 Národní strategie umělé inteligence v České republice [online]. Ministerstvo průmyslu a obchodu, 2019 [cit. 2019-09-29]. Dostupné na: https://www.vlada.cz/assets/evropske-zalezitosti/umela-inteligence /NAIS_kveten_2019.pdf.

34 Etickým a právním otázkám se v této strategii věnuje kapitola č. 6, která do budoucna mimo jiné předpokládá zřízení expertní Platformy a fóra pro průběžné monitorování právních a etických pravidel a nástrojů na národní a mezinárodní úrovni týkajících se výzkumu, vývoje a využívání umělé inteligence.

35 McKinsey Global Institute. A Future That Works: Automation, Employment and Production [online]. 2017 [cit. 2019-09-29]. Dostupné na: https://www.mckinsey.com/ /media/mckinsey/featured\%20insights /Digital\%20Disruption/Harnessing\%20automation\%20for\%20a\%20future\%20that\%20works/MGI-A -future-that-works-Full-report.ashx.

$36 \mathrm{PwC}$. Will robots really steal our jobs? An international analysis of the potential long term impact of automation [online]. 2018 [cit. 2021-02-23]. Dostupné na: https://www.pwc.com/hu/hu/kiadvanyok/assets/pdf /impact_of_automation_on_jobs.pdf.

37 K tomu více viz KRAUSOVÁ - MATEJKA - IVANČO - ŽOLNERČÍKOVÁ - ŠČÉRBA, $c . d$.

38 Včetně např. ,,chytrých“ rukavic, jež mohou číst informace ze strojů ručně a dokumentovat či sledovat pracovní fáze. 
takzvaní „coboti“ “(,spolupracující roboti“) budou vykonávat práci společně s pracovníky (ostatně již dnes v automobilovém průmyslu coboti pomáhají pracovníkům s montáží vybraných komponent). Dynamiku rozvoje v minulosti potvrzují i odhady o tom, že počet průmyslových robotů vzroste z 1,6 milionu v roce 2015 na 2,6 milionu v roce 2019.39

Právě spolupráce člověka a autonomních systémů, včetně přesahu do oblasti odpovědnosti a samotného pojetí organizace práce, se tak jeví jako jedna z hlavních výzev pro budoucí regulaci pracovněprávních vztahů. $\mathrm{V}$ rámci tohoto operativního propojení technologie a lidské práce, přičemž standardní modely ochrany mohou být do jisté míry narušeny, lze považovat za legitimní hledat přiléhavější režim jejich právní regulace. Systémy umělé inteligence jsou již dnes v rámci této spolupráce hojně využívány, a to nejenom jako systémy automatizující rutinní operace, ale jako relativně samostatné tvůrčí činnosti. Př́́kladem tohoto typu může být nezpochybnitelný tvůrčí potenciál těchto systémů demonstrovaný např. v oblasti výtvarného umění (projekt Next Rembrand $t^{40}$ ), príípadně hudby (projekt Beyond the Fence ${ }^{41}$ ), včetně řady dílčích duševně tvůrčích aspektů přesahujících režim pracovněprávních předpisů. ${ }^{42}$

Systémy umělé inteligence tak již dnes pracují určitým komparačně-analytickým způsobem, kdy na základě zadaného souboru dat vytvoří dílo, jež je smysly vnímatelné jako standardní předmět duševního vlastnictví, a to včetně předmětů, jež byly donedávna vyhrazeny pouze a jen člověku ${ }^{43}$ Tyto výtvory si jistě zaslouží svou právní ochranu, nebot' její absence by vedla k popření základní utilitaristické myšlenky práva duševního vlastnictví, at' již práva autorského, či patentového, tj. motivovat k tvůrčí činnosti autora (původce). Nehledě na skutečnost, že případná komercionalizace takto nechráněných výtvorů by nutně vedla $\mathrm{k}$ nepř́ípustné alokaci finančních prostř̌edků směrem $\mathrm{k}$ subjektům, kterým nemají primárně náležet, navíc by popírala právní jistoty jak autorů samotných, tak i samotných uživatelů (konzumentů) těchto předmětů. Lze jistě souhlasit, že i současné právo poskytuje určitou obecnou oporu (napřr. prostředky nekalé soutěže) proti zásahům tohoto typu, nicméně i tyto otázky je třeba důsledně analyzovat naprríč obory a hledat cesty směřující $\mathrm{k}$ nalezení optimálního rámce ochrany $\mathrm{k}$ výtvorům, kde hlavní roli při jejich tvorbě nehrál pouze člověk, ale jež prokazatelně vznikly na základě určité „spolupráce“ člověka a systému umělé inteligence.

39 Viz KLEBE - WEISS, $c . d .$, s. 264.

40 GUADAMUZ, A. Artificial intelligence and copyright. WIPO magazine [online]. 2017 [cit. 2021-02-23]. Dostupné na: http://www.wipo.int/wipo_magazine/en/2017/05/article_0003.html.

41 BROWN, M. World's first computer-generated musical to debut in London. The Guardian [online]. 1. 12. 2015 [cit. 2018-04-12]. Dostupné na: https://www.theguardian.com/stage/2015/dec/01 /beyond-the-fence-computer-generated-musical-greenham-common?curator=MusicREDEF.

42 Viz např. GUADAMUZ, A. Can the monkey selfie case teach us anything about copyright law? WIPO magazine [online]. 2018 [cit. 2021-02-23]. Dostupné na: http://www.wipo.int/wipo_magazine/en/2018/01 /article_0007.html.

43 Viz např. MAZZI, F. Patentability of AI Generated Drugs. European Pharmaceutical Law Review (EPLR). 2020, Vol. 4, No. 1, s. 17-33. 


\section{ZÁVĚR}

Je obecně známo, že právo se ustavičně nachází na určité pomyslné křižovatce, kde se řada právních odvětví musí potýkat s otázkou, zda vybrané právní předpisy více či méně nezaostávají za reálným ekonomickým životem, případně zda současné předpisy odpovídají stavu současného poznání a technologickým možnostem, případně zda vůbec nějak, a pokud ano, tak zda efektivně reagují na související praktické potřeby svých adresátů. V tomto ohledu je tak normativní vztah práva a nových technologií nezřídka předmětem odborného i vědeckého zájmu ${ }^{44}$ řada klíčových otázek však ze své podstaty zůstává neřešena, řada dalších problémů se nachází pouze ve fázi jejich identifikace, případně průběžné analýzy.

Tato skutečnost, tj. že právo je opakovaně konfrontováno s rozvojem techniky a technologickým pokrokem, nepředstavuje nic až tak nového, nicméně v řadě případů se ukazuje, ${ }^{45}$ že lze tyto problémy řešit analogicky za využití existujících právních institutů, jež mají obecnou povahu, př́padně regulují obdobnou problematiku. $Z$ pohledu řešené materie $\mathrm{v}$ oblasti zaměstnanosti a trhu práce je tak nepochybné, že současný sociální vývoj, jakož i související poptávka po vyvážené právní ochraně, bude klást výrazně vyšší nároky na činnost odborových organizací, zástupců zaměstnanců a zaměstnavatelů, jakož i celé řady dalších entit způsobilých více či méně spolurozhodovat se zaměstnavateli. Za př́klad může sloužit i německý zákon o podnikových radách, jež není ve smyslu své působnosti omezen pouze na standardní zaměstnance, ale také na širší okruh pracovníků ve smyslu zvláštního zákona o pracovnících v domácnosti. ${ }^{46}$ $\mathrm{Z}$ určitého pohledu se tak jeví jako nezbytné překonat dosavadní představy vymezující výkon závislé práce, jakož i vztahy podřízenosti a nadřízenosti, a najít vhodnou ochranu odpovídající požadavkům moderní (technologické) doby.

Jakkoliv bude vždy obtížné najít jasnou hranici mezi zaměstnáním a samostatnou výdělečnou činností, a to např́č desítkami různých platforem a technologií, je třeba důsledně vyvažovat otázku ochrany, podpory a rozvoje pozitivních stránek těchto technologií, jakož i současné vytváření efektivních překážek a regulace všech jejich negativních důsledků pro společnost či jednotlivce. Úvahy v tomto smyslu nutno ubírat zejména směrem k zachování minimálních standardů existující míry právní ochrany ve světle možných faktických důsledků budoucí aplikace konkrétní technologie v novém právním prostředí. ${ }^{47}$

44 Viz např. POLČÁK, R. Kódování práva. Právník. 2012, roč. 151, č. 1, s. 52-80; POLČÁK, R. Internet a proměny práva. Praha: Auditorium, 2012; POLČÁK, R. - ČERMÁK, J. - LOEBL, Z. - GŘIVNA, T. - MATEJKA, J. - PETR, M. Cyber Law in the Czech Republic. Alphen aan den Rijn: Kluwer Law International, 2012. Encyclopaedia of Laws: Cyberlaw.

$45 \mathrm{~K}$ tomu více viz např. MATEJKA, J. Internet jako objekt práva: hledání rovnováhy autonomie a soukromí. Praha: CZ.NIC, 2012, s. 12.

46 Samotná otázka, zda pracovníci předmětných digitálních platforem spadají do této zákonné kategorie, je sporná a lze ji určit pouze $v$ každém jednotlivém př́ípadě, protože zaměstnání může mít mnoho různých forem. Pojem zaměstnanec v Německu byl významně rozvinut judikaturou a nedávno začleněn do legislativy. K tomu více viz KLEBE - WEISS, c.d., s. 280.

47 Je však nutné korektně poznamenat, že některé výrazně starší technologické změny měly podstatu práva ovlivnit také, byt' je v současné době zjevné, že se tak nestalo. Jako jeden př́klad za všechny lze uvést vlnu nadšení z nových možností poznání (včetně možností právní vědy), která se objevila již v šedesátých 
K naprosté většině nových digitálních platforem je třeba zaujmout především určitý komplexní přístup, tj. neanalyzovat jednotlivé platformy pouze pohledem paradigmat určitých oborově vymezených a přijímaných schémat, tj. nap̌r. z pohledu fiskálního, ekonomického, sociálního či právního, jež zpravidla dávají rozdílný pohled neumožňující nalezení férového modu vivendi těchto platforem. Nutno tak především apelovat na fakt, že všichni pracovníci by měli být nadáni určitými univerzálními sociálními právy, a to bez nutnosti kvalifikovat se do určité skupiny oprávněných osob, tj. hledat optimální obecný režim standardů právní ochrany těchto pracovníků, jež povede jak k jejich minimální sociální ochraně, tak i k důsledné aplikaci souvisejících právních i technologických záruk; to vše se zřetelem na právní rámec určité minimalistické veřejnoprávní regulace směřující k ochraně jejich sociálních práv, kde, jak ostatně trefně poznamenal V. Güttler, ${ }^{48}$ na vedoucím místě by měla stát ochrana základního práva na lidskou důstojnost, tedy práva, k jehož naplnění prakticky téměř všechna ostatní lidská práva přímo či nepřímo směřují.

JUDr. Ján Matejka, Ph.D.

Ústav státu a práva AV ČR, v. v. i.

matejka@ilaw.cas.cz

letech. K tomu více viz např. KNAPP, V. O možnosti použití kybernetických metod v právu. Praha: Nakladatelství ČSAV, 1963, jež tehdy otevřela zcela nový pohled na vliv technologie na právo a která se na nějaký čas stala inspirací pro rozvoj oboru.

48 GÜTTLER, V. in: GÜTTLER, V. - MATEJKA, J. K otázkám některých základních lidských práv a svobod v souvislosti s právní ochranou biometrických údajů. Právník. 2016, roč. 155, č. 12, s. 1055. 